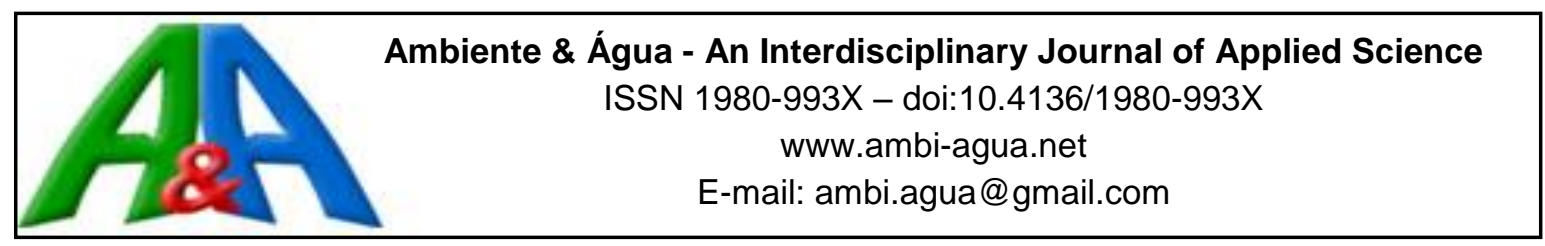

\title{
Evaluation of the Sagittaria montevidensis Cham. \& Schltdl. as a bioindicator and phytoextractor of toxic metals
}

\author{
doi:10.4136/ambi-agua.2086
}

Received: 30 Jan. 2017; Accepted: 29 Aug. 2017

\begin{abstract}
Edila Maria Kickhöfel Ferrer*; Glauco Rasmussen Betemps; Nathaly Nunes da Rosa; Pedro José Sanches Filho

Instituto Federal de Educação, Ciência e Tecnologia Sul-rio-grandense (IFSul), Pelotas, RS, Brasil Grupo de Pesquisa em Contaminantes Ambientais (GPCA). E-mail: edila.ferrer@gmail.com, glauco.betemps@gmail.com, nathaly_nrosa@hotmail.com, pjsans@ibest.com.br

*Corresponding author
\end{abstract}

\begin{abstract}
This study evaluated the bioindication and phytoremediation capacity of the aquatic macrophyte Sagittaria montevidensis by using it to assess the bioconcentration and translocation of heavy metals. A simple sampling was conducted at four sites in the region of Pelotas, southern Brazil, where plants, water and sediments were collected. The plants were subjected to nitric-perchloric acid digestion and the sediments underwent pseudo-total acid digestion. The determination of the elements $\mathrm{Cr}, \mathrm{Cu}, \mathrm{Pb}, \mathrm{Ni}$ and $\mathrm{Zn}$ in the extracts was performed by flame atomic absorption spectrometry. Physicochemical tests were also carried out on water samples, including $\mathrm{pH}$, electrical conductivity, chlorides, alkalinity, hardness and organic matter, and in sediment samples, moisture and organic matter content. The macrophyte study indicated a Bioconcentration Factor (BCF) and a Translocation Factor (TF), especially for Ni. The results showed that the aquatic macrophyte species $S$. montevidensis has a phytoextraction capacity, mainly for $\mathrm{Ni}$, and potentially for bioindication of $\mathrm{Cu}, \mathrm{Ni}$ and $\mathrm{Zn}$.
\end{abstract}

Keywords: aquatic macrophyte, heavy metals, phytoremediation.

\section{Avaliação da Sagittaria montevidensis Cham. \& Schltdl. como bioindicador e fitoextrator de metais tóxicos}

\section{RESUMO}

Este estudo teve como objetivo avaliar a capacidade de fitorremediação e bioindicação da macrófita aquática Sagittaria montevidensis, utilizando como parâmetros a bioconcentração e translocação de metais pesados. Foi realizada uma amostragem simples em quatro locais na região de Pelotas, sul do Brasil, na qual foram coletadas plantas, águas e sedimentos. As plantas foram submetidas a digestão ácida nítrico-perclórica e os sedimentos sofreram a extração pseudo-total de digestão ácida. A determinação dos elementos $\mathrm{Cr}, \mathrm{Cu}, \mathrm{Pb}, \mathrm{Ni}$ e $\mathrm{Zn}$ nos extratos foi realizada por espectrometria de absorção atômica em chama. Também foram realizados ensaios físico-químicos em amostras de água, incluindo $\mathrm{pH}$, condutividade elétrica, cloretos, alcalinidade, dureza e matéria orgânica e, em amostras de sedimentos, umidade e teor de matéria orgânica. A macrófita aquática estudada apresentou Fator de Bioconcentração (FBC) e Fator de Translocação (FT), principalmente de Ni. Os resultados obtidos mostraram que a 
macrófita aquática da espécie $S$. montevidensis possui capacidade para fitoextração, principalmente de $\mathrm{Ni}$ e potencial para bioindicação de $\mathrm{Cu}$, Ni e Zn.

Palavras-chave: fitorremediação, macrófita aquática, metais pesados.

\section{INTRODUCTION}

Population growth and lack of urban planning can create disruptions that negatively impact the environment and consequently result in damage to human health (Brasil, 2006). Heavy metals may be derived from natural sources or from human activities. These metals may migrate to uncontaminated areas by bleaching through the soil or by the propagation of sewage sludge (Ali et al., 2013; Tangahu et al., 2011). These metals can be incorporated into the food chain, increasing their biological magnification (Ali et al., 2013).

Aquatic macrophytes are more suitable for the treatment of sewage rather than land plants because they have a fast-growing, large biomass production and high capacity for absorbing pollutants. This type of vegetation purifies more efficiently when it is in direct contact with contaminated water (Ali et al., 2013). These plants also have a great potential for the removal or reduction of water pollutants, including heavy metals, phosphorus and nitrogen.

Phytoremediation is one of the most-used techniques for the removal of heavy metals in soil, sediment or polluted waters. In this process, the roots of the plants capture pollutants from water and soil, translocating them and storing them in the available biomass. There are different phytoremediation processes, such as phytofiltration, phytostabilization, phytovolatilization, phytodegradation and phytoextraction (or phytoacumulation). Phytoremediation usually occurs in hyperaccumulator plants that are resistant to pollutants (Ali et al., 2013; Tangahu et al., 2011).

Phytoextraction can remove heavy metals from soil by using the ability of plants to absorb metals that are essential for their growth, such as $\mathrm{Fe}, \mathrm{Mn}, \mathrm{Zn}, \mathrm{Cu}, \mathrm{Mg}$, $\mathrm{Mo}$ and $\mathrm{Ni}$, and also by the ability of plants to accumulate non-essential metals ( $\mathrm{Cd}, \mathrm{Cr}, \mathrm{Pb}, \mathrm{Co}, \mathrm{Ag}, \mathrm{Se}, \mathrm{Hg}$ ) (Tangahu et al., 2011).

Dhir et al. (2009) reports that, although the level of uptake potential varies from species to species, and by species of plant and wetland, the free-floating plant, particularly when submerged and emerging, gained major importance in the world by its efficiency in removing various contaminants such as heavy metals, radionuclides, explosives, organic and inorganic pollutants in polluted waters. For this reason, various aquatic plants have been used to remove heavy metals from wastewater (Vardanyan and Ingole, 2006).

Plant indicators of metal ions have the ability to accumulate heavy metals in their aerial parts. They therefore reflect the concentrations of the substrate (Sheoran et al., 2011).

Pelotas city is located on the shores of the São Gonçalo channel, in the State of Rio Grande do Sul, southern Brazil. This channel connects the Patos and Mirim Lagoons, which are the largest in the country. The region has a humid subtropical climate that is suitable for the development of several kinds of emerging aquatic weeds such as Echinodorus ssp (Bevilaqua et al., 2001) and Sagittaria montevidensis Cham. \& Schltdl. (Demarco et al., 2016), which belong to the Alismataceae family.

The aquatic macrophyte Sagittaria montevidensis Cham. \& Schltdl. (Figure 1), also known as arrowhead or giant arrow, is native to South America; depending on climatic conditions, its appearance may be annual or perennial. It occurs in polluted waters like open-air sewage channels and can reach a height of $1.5 \mathrm{~m}$, but in unpolluted waters it reaches 0.2 to $0.60 \mathrm{~m}$ (Andrade et al., 2007). Fruits are achenes (Cassol et al., 2008). 

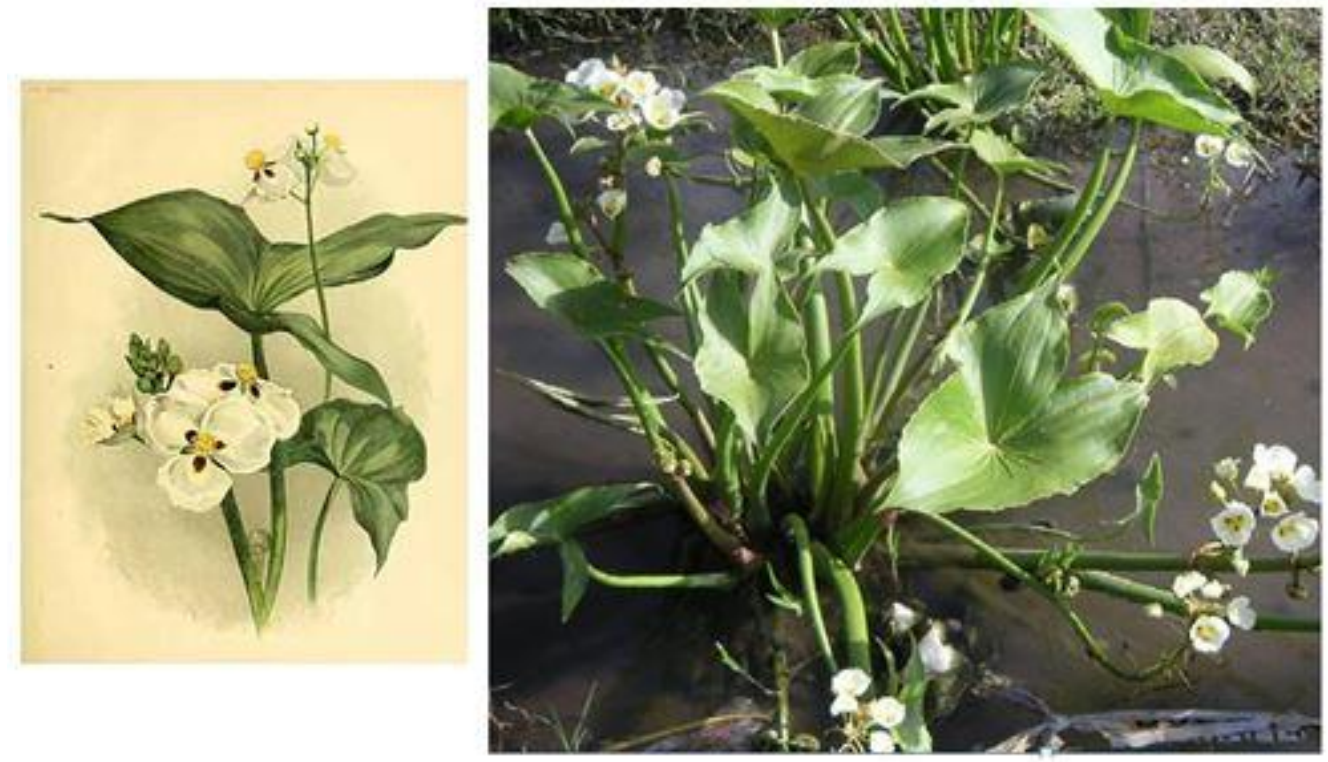

Figure 1. Shows images of Sagittaria montevidensis Cham. \& Schltdl.

Source: http://www.plantillustrations.org/; https://www.flickr.com.

This plant is a problem in southern Brazil, mainly in the States of Santa Catarina and Rio Grande do Sul, since it is an aquatic weed that invades rice fields and infests irrigation channels and drainage (Cassol et al., 2008). Moreover, this category of plant is considered to be a weed since it has high biomass production rate which can lead to obstruction and changes in aquatic environments (Thomaz and Bini, 2003).

Although there are numerous studies in the scientific community on aquatic plants, wetland systems and phytoremediation of trace metals, there are few studies related to the use of S. montevidensis for such purposes. Molisani et al. (2006) studied the concentration of $\mathrm{Hg}$ in aquatic macrophytes from two reservoirs in Paraíba do Sul - Rio Guandu (Sergipe) - Brazil. One of the plants, the $S$. montevidensis Bogin, presented $103 \pm 4 \mathrm{ng} \mathrm{g}^{-1}$ in its leaves and $62 \pm 35 \mathrm{ng} \mathrm{g}^{-1}$ in its roots. Bregunce et al. (2011) reports the efficient removal of organic matter and coliforms in a wetland systems by $S$. montevidensis.

The choice of $S$. montevidensis in this study is justified by its abundance in our region. Another point is the scarcity of data on the phytoremediation and bioindication behavior towards metals presented by its emerging macrophytes. Since it is easily developed naturally in unpolluted places and abundant in areas with high levels of pollution, it shows high rates of above ground biomass and good adaptation to previaling environmental and climatic conditions (Ali et al., 2013).

The bioconcentration factor (BCF) and the translocation factor (TF) are indexes used to check the efficiency of phytoextraction process. BCF is the ratio of the concentration of the plant and sediment concentrations. The TF is the relationship between the concentration of the plant and root concentrations (Sanches Filho et al., 2015; Ali et al., 2013).

Some authors, such as Ali et al. (2013), Dhir et al. (2009) and Balabanova et al. (2015), report that a BCF greater than 1 indicate that a TF plant species has potential for phytoextraction. However, if the translocation factor is greater than 1 , the plant has a higher capacity for metal accumulation in its leaves and stems rather than in its roots.

This study evaluated the aquatic macrophyte S. montevidensis as a trace for metal bioaccumulation potential $(\mathrm{Cr}, \mathrm{Cu}, \mathrm{Pb}, \mathrm{Ni}$ and $\mathrm{Zn})$ in contaminated areas and evaluated the storage capacity for these elements in the selected species, discussing their potential for use in phytoremediation and bioindication. 


\section{MATERIAL AND METHODS}

\subsection{Reagents}

All reagents used were of analytical grade. Concentrated nitric acid $(65 \% \mathrm{v} / \mathrm{v})$ and perchloric acid $(70 \% \mathrm{v} / \mathrm{v})$ were used for digestion of the samples.

For the calibration curve range of 0.2 to $6.0 \mathrm{mg} \mathrm{L}^{-1}$, standards were prepared from stock $1.000 \mathrm{mg} \mathrm{L}^{-1}$ solutions $\mathrm{Cr}, \mathrm{Cu}, \mathrm{Ni}, \mathrm{Pb}$ and $\mathrm{Zn}$, each on the brand of Titrisol ${ }^{\circledR}$ - Merck.

\subsection{Equipment}

The equipment used was: Atomic Absorption Spectrometer flame, GBC Brand, Model 932 plus air/acetylene; $\mathrm{pH}$ meter: Homis, MOD. 801; portable conductivity meter, Instrutherm MOD. CD-830; oven with forced air circulation; drying oven; muffle furnace; digester block; warming plate; water purifier.

\subsection{Sample collection}

Sampling was carried out from September to November, 2014. Plant samples, sediment and water were collected.

Four sites were chosen (Figure 2) located either near the city of Pelotas/Rio Grande do Sul or inside the city, where $S$. montevidensis occurs naturally. Three of the sites were considered to be urban areas contaminated by residential and urban sewage, and in these locations a large concentration of these plants was found. The fourth place had a lower concentration of these plants.

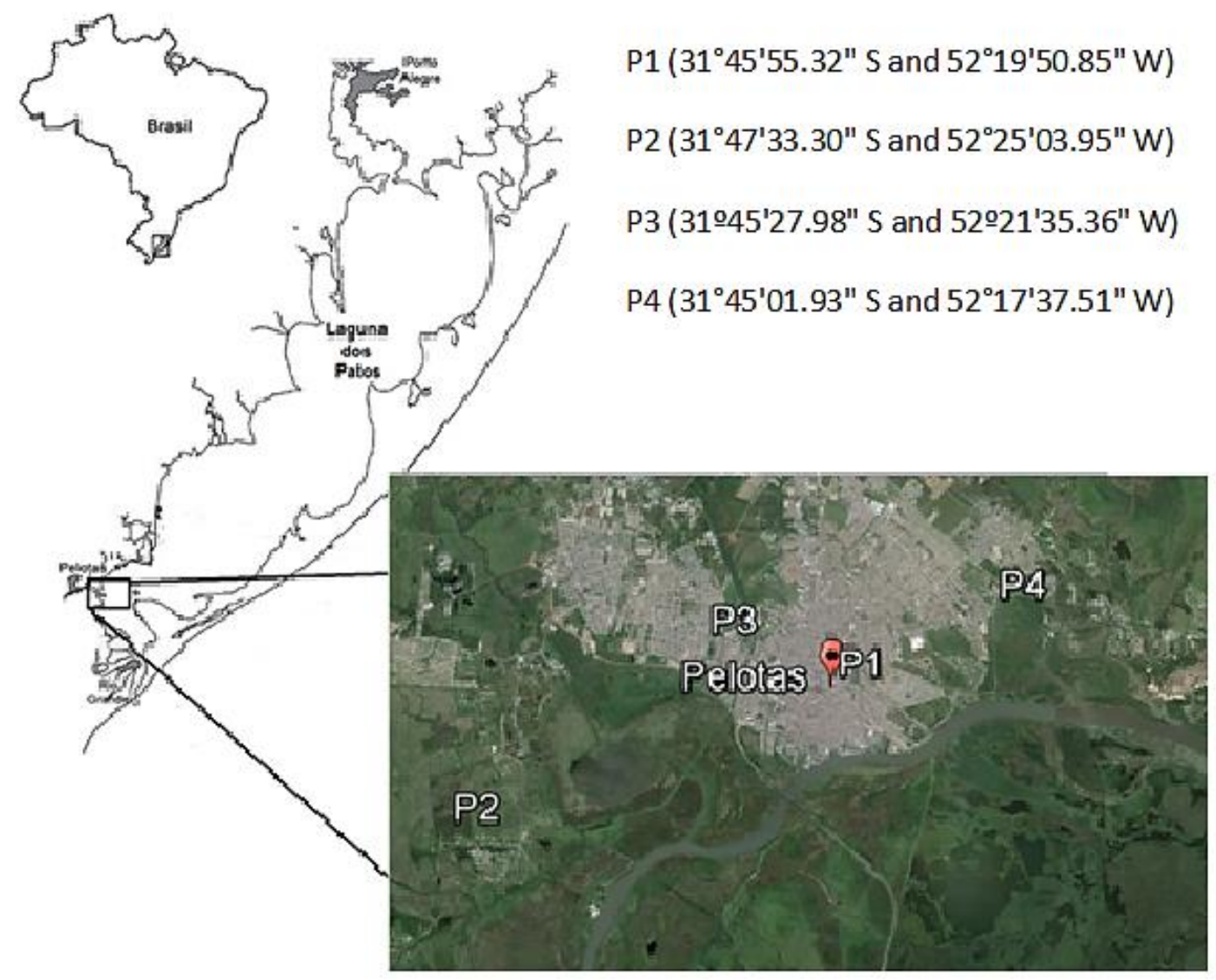

Figure 2. Location of the sampling points. Source: Google Maps. 
The plants were chosen by visual observation. At all collection points, plants with the same patterns were chosen: size, width and color of leaves; stem length and diameter; and the presence of fruit.

Point 1 - P1 (31 ${ }^{\circ} 45^{\prime} 55.32^{\prime \prime} \mathrm{S}$ and $\left.52^{\circ} 19^{\prime} 50.85^{\prime \prime} \mathrm{W}\right)$ is one of the main storm water draingage channels and urban sewage receivers passing through urban and heavy vehicle traffic areas. At this location there was a great predominance of S. montevidensis. Point 2 - P2 (31 ${ }^{\circ} 47^{\prime} 33.30^{\prime \prime} \mathrm{S}$ and $52^{\circ} 25^{\prime} 03.95^{\prime \prime} \mathrm{W}$ ) is a swamp in a rural area. Despite the diversity of aquatic vegetation characteristic of wetlands, only a few units of the species studied were found. Point 3 - P3 $\left(31^{\circ} 45^{\prime} 27.98^{\prime \prime} \mathrm{S}\right.$ and $\left.52^{\circ} 21^{\prime} 35.36^{\prime \prime} \mathrm{W}\right)$ is a water-receiver channel, located at the junction of two paved avenues with an intense flow of motor vehicles. There were a variety of aquatic plants, especially $S$. montevidensis, along the flooded extension, but in smaller quantities than P1. Point 4 - P4 (31 ${ }^{\circ} 45^{\prime} 01.93 " \mathrm{~S}$ and $\left.52^{\circ} 17^{\prime} 37.51^{\prime \prime} \mathrm{W}\right)$ is a rainwater drainage ditch and a local sewage receiver, rich in aquatic vegetation in some isolated points, where the species were collected.

\subsection{Sample preparation}

The materials used in handling and storage of the samples were subjected to decontamination by means of acidic solution of $\mathrm{HNO}_{3}$ at $10 \%(\mathrm{v} / \mathrm{v})$ for 24 hours and then rinsed with ultrapure water. Plant parts such as leaves, stems, fruits/seeds and roots; sediments and water were also collected manually. Afterwards, the plants were collected, stored and transposed in plastic bags.

Sediments and water were stored and transported in previously decontaminated and properly identified plastic containers. The $\mathrm{pH}$ was determined by potentiometric method by using a digital $\mathrm{pH}$ meter; the electrical conductivity $\left(\mathrm{EC} \mu \mathrm{S} \mathrm{cm}^{-1}\right)$ was analyzed by a portable conductivity meter. The samples of water and sediment were stored under refrigeration in order to determine physicochemical parameters.

The plant samples were washed in water to remove debris and sediments, and then rinsed with distilled water. After that, they were separated into stem, leave, fruit/seed and root, then finely chopped. These materials were dried in a convection oven at $60^{\circ} \mathrm{C}$ for $72 \mathrm{~h}$. The dried samples were ground using a porcelain mortar and pestle. About $0.5 \mathrm{~g}$ of each sample was weighed for chemical extraction. The samples were subjected to nitric perchloric digestion according to Abreu et al. (2004), with $4 \mathrm{~mL}$ of concentrated $\mathrm{HNO}_{3}$ and $1 \mathrm{~mL}$ of concentrated $\mathrm{HClO}_{4}$ added to the samples in glass tubes to block the digester at $210^{\circ} \mathrm{C}$ until no further white smoke was formed. After cooling, the extracts were filtered with qualitative filter paper into $50 \mathrm{~mL}$ volumetric flasks and the volume was made-up with ultrapure water.

The sediment samples were dried at $60^{\circ} \mathrm{C}$ for $48 \mathrm{~h}$, followed by maceration and screening, and the fraction $<63 \mu \mathrm{m}$ was chosen for chemical extraction. To this end, $2 \mathrm{~g}$ of each sediment sample was weighed. Samples were mixed with $4 \mathrm{~mL}$ of aqua regia $\left(3: 1 \mathrm{HCl}: \mathrm{HNO}_{3}\right), 1 \mathrm{~mL}$ of high-purity water and $1 \mathrm{~mL}$ of $\mathrm{HClO}_{4}$ in $50 \mathrm{~mL}$ beakers covered with watch glass and heated for 30 minutes at $90^{\circ} \mathrm{C}$ in a water bath by using the procedure of Hortellani et al. (2005). After cooling, the samples were filtered through qualitative filter paper into volumetric flasks of $25 \mathrm{~mL}$ and the volume was made-up with ultrapure water.

The blanks and the certified reference material were run with set.

\subsection{Determination of Metals}

The analytes were determined by flame Atomic Absorption Spectrometry (AAS).

Reference materials such as the BCR-060 (Lagarosiphon major, Aquatic plant), the BCR-596 (Trapa natans, Aquatic plant), and the NMCR \# 4 (Natural Matrix Certified Reference soil and sediment) were used to control recovery procedures and analyses of the samples. 
The blank reading was performed 10 times to calculate the limit of quantification (LOQ) and the limit of detection (LOD) of the equipment and they were calculated based on the average standard deviation (SD) for the LOQ blank signal plus 10 times the signal blank average and also plus 3 times the SD for the LOD (IUPAC, 1997).

The relationship between concentrations in the sediment and in the plants, was evaluated by the correlation coefficient Pearson using the Microsoft Excel ${ }^{\circledR}$ software.

The bioconcentration factor (BCF) and the translocation factor (TF) were calculated in all the investigated plants, and this was carried out by using Equations 1 and 2 (Ali et al., 2013).

$$
\begin{aligned}
& \mathrm{BCF}=\mathrm{C}_{\text {harvested tissue }} / \mathrm{C}_{\text {sediment }} \\
& \mathrm{TF}=\mathrm{C}_{\text {shoot }} / \mathrm{C}_{\text {root }}
\end{aligned}
$$

where:

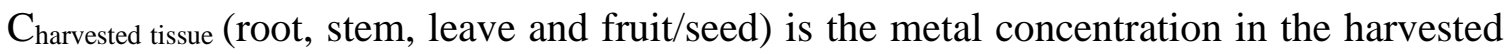
tissues;

$\mathrm{C}_{\text {sediment }}$ is the metal concentration in the sediment; $\mathrm{C}_{\text {shoot }}$ is the metal concentration in the shoots (stem, leave and fruit/seed); and $\mathrm{C}_{\text {root }}$ is the metal concentration in the root.

\subsection{Physicochemical assays}

Among the tests performed in the laboratory relating to sediment, the moisture content assay was conducted by gravimetric method at a temperature of $110-115^{\circ} \mathrm{C}$ in a drying oven for $24 \mathrm{~h}$, weighing $30 \mathrm{~g}$ (APHA, 2005). The organic content was determined by weight loss method calcined in a muffle at $550^{\circ} \mathrm{C}$ for $4 \mathrm{~h}$, with a weight of $2 \mathrm{~g}$ of dry sample (Mirlean et al., 2003).

For physicochemical tests of water, titrimetric determinations of chlorides, alkalinity, hardness and organic matter were carried out according to APHA (2005).

All determinations were performed in triplicate.

\section{RESULTS AND DISCUSSION}

\subsection{Physicochemical parameters}

The conductivity values (Table 1), shown at all points, were above the maximum value for unpolluted waters, which is $100 \mu \mathrm{S} \mathrm{cm}$, according to the Cetesb (2009). In general, it is observed that the conductance values are associated with chloride level and the presence of calcium and magnesium salts. The values of conductivity, especially for points P1, P3 and P4, may be due to the drainage of urban and domestic sewage. The conductivity of $\mathrm{P} 2$ was lower in relation to other points; perhaps because it belongs to a less urbanized area, and the values of alkalinity and hardness were similar. Alkalinity measures the amount of reflected carbonate in water. The water has the ability to neutralize soil acidity and that indicates the capacity of the sewage water to enhance the growth of algae (Sarkinnoma et al., 2013).

The results of chlorides did not exceed the limits established by Resolution CONAMA 357/2005 for fresh water Class 3 in any of the points (Conama, 2005).

The values presented show a variation of $\mathrm{pH}$ from 5.9 to 6.7. The $\mathrm{pH}$ values in $\mathrm{P} 3$ and $\mathrm{P} 4$ points were found to be slightly below the standards established by the Resolution CONAMA 357/2005 (Conama, 2005).

These results indicate the sampling locations P1, P3 and P4 are the most impacted; this was expected in these points because they are located in more urbanized areas.

High moisture values are related to the presence of interstitial water that relates directly to a smaller particle size. Water retention in the soil occurs due to the action of adhesion between the water molecules and solid particles and the cohesion between the water molecules themselves. The smaller the particle size of the sediment, the greater the surface area indicates 
these locations are prone deposits and concentration of environmental contaminants which are introduced in such environments (Caldas and Sanches Filho, 2013).

Table 1. Physicochemical parameters in water and sediment samples collected from point P1, P2, P3 and $\mathrm{P} 4$.

\begin{tabular}{|c|c|c|c|c|c|}
\hline & \multirow{2}{*}{ Physicochemical parameters } & \multicolumn{4}{|c|}{ POINTS } \\
\hline & & $\mathrm{P} 1$ & $\mathrm{P} 2$ & P3 & $\mathrm{P} 4$ \\
\hline \multirow{6}{*}{$\begin{array}{l}\dot{\bar{d}} \\
\overrightarrow{\tilde{z}} \\
\dot{z}\end{array}$} & $\mathrm{pH}$ & 6.7 & 6.3 & 5.9 & 5.9 \\
\hline & Electrical Conductivity $\left(\mu \mathrm{S} \mathrm{cm}^{-1}\right)$ & 764.8 & 138.4 & 549.5 & 694.2 \\
\hline & Alkalinity $\pm \mathrm{SD}\left(\mathrm{CaCO}_{3} \mathrm{mg} \mathrm{L}^{-1}\right)$ & $420.0 \pm 0.1$ & $82.5 \pm 3.5$ & $217.5 \pm 3.5$ & $280.0 \pm 14.1$ \\
\hline & Chloride $\pm \mathrm{SD}\left(\mathrm{Cl}^{-} \mathrm{mg} \mathrm{L}^{-1}\right)$ & $5.1 \pm 0.1$ & $0.9 \pm 0.1$ & $1.5 \pm 0.1$ & $5.3 \pm 0.1$ \\
\hline & Hardness $\pm \mathrm{SD}\left(\mathrm{CaCO}_{3} \mathrm{mg} \mathrm{L}^{-1}\right)$ & $87.5 \pm 2.1$ & $33.5 \pm 2.1$ & $113.0 \pm 1.4$ & $85.0 \pm 1.4$ \\
\hline & Matter Organic $\pm \mathrm{SD}\left(\mathrm{mg} \mathrm{O}_{2} \mathrm{~L}^{-1}\right)$ & $77.7 \pm 0.1$ & $24.7 \pm 1.0$ & $13.6 \pm 0.1$ & $20.9 \pm 0.4$ \\
\hline \multirow{2}{*}{ 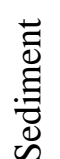 } & Moisture \pm SD $(\%)$ & $70.1 \pm 0.7$ & $60.7 \pm 0.1$ & $52.7 \pm 0.2$ & $46.6 \pm 1.2$ \\
\hline & Organic Content $\pm \mathrm{SD}$ (\% dry weight $)$ & $19.2 \pm 2.6$ & $11.4 \pm 0.1$ & $14.5 \pm 0.9$ & $7.4 \pm 1.7$ \\
\hline
\end{tabular}

SD - Standard Deviation.

In this paper, P1 is the place with higher humidity values in sediment, which indicates a favorable environment for settling and accumulation of contaminants. This situation is confirmed by the levels of organic matter found at that point.

\subsection{Study of metal}

The results from sediment samples (Table 2) show the concentration variations of each metal detected: $\mathrm{Cr}\left(2.7 \pm 0.2\right.$ to $\left.25.7 \pm 3.5 \mathrm{mg} \mathrm{kg}^{-1}\right), \mathrm{Cu}\left(7.6 \pm 0.1\right.$ to $\left.40.0 \pm 0.2 \mathrm{mg} \mathrm{kg}^{-1}\right), \mathrm{Ni}(<\mathrm{LOQ}$ to $\left.5.1 \pm 0.3 \mathrm{mg} \mathrm{kg}^{-1}\right)$ and $\mathrm{Zn}\left(26.7 \pm 0.7\right.$ to $\left.514.1 \pm 15.5 \mathrm{mg} \mathrm{kg}^{-1}\right)$. The highest concentration for each metal found in P1 is followed by points P3 and P4. Point P2 was the place where there was the lowest concentration.

Table 2. Concentrations of different metals in different parts of macrophyte (root, stem, leaf and fruit or seeds) and in sediment (dry basis) $\mathrm{mg} \mathrm{kg}^{-1} \pm \mathrm{SD}^{(1)}$ in P1, P2, P3 and P4.

\begin{tabular}{|c|c|c|c|c|c|c|c|}
\hline Points & & Sample & $\mathrm{Cr} \pm \mathrm{SD}$ & $\mathrm{Cu} \pm \mathrm{SD}$ & $\mathrm{Pb} \pm \mathrm{SD}$ & $\mathrm{Ni} \pm \mathrm{SD}$ & $\mathrm{Zn} \pm \mathrm{SD}$ \\
\hline \multirow{11}{*}{ P1 } & Root & $\mathrm{FBC}^{(3)}$ & $\mathrm{ND}^{(2)}$ & $\begin{array}{c}11.1 \pm 0.7 \\
0.3\end{array}$ & ND & $\begin{array}{c}20.8 \pm 0.4 \\
4.1\end{array}$ & $\begin{array}{c}168.8 \pm 0.4 \\
0.3\end{array}$ \\
\hline & & & ND & $12.0 \pm 2.6$ & ND & $25.2 \pm 1.0$ & $88.5 \pm 1.0$ \\
\hline & Stem & FBC & & 0.4 & & 4.9 & 0.2 \\
\hline & & $\mathrm{FT}^{(4)}$ & & 1.1 & & 1.2 & 0.5 \\
\hline & & & ND & $10.3 \pm 0.3$ & ND & $47.6 \pm 6.8$ & $99.0 \pm 6.8$ \\
\hline & Leaf & FBC & & 0.3 & & 9.3 & 0.2 \\
\hline & & FT & & 0.9 & & 2.3 & 0.6 \\
\hline & & & ND & $6.8 \pm 0.3$ & ND & $12.6 \pm 1.0$ & $111.1 \pm 1.0$ \\
\hline & $\mathrm{F} / \mathrm{S}^{(5)}$ & FBC & & 0.2 & & 2.5 & 0.2 \\
\hline & & FT & & 0.6 & & 0.6 & 0.7 \\
\hline & Sediment & & $25.7 \pm 3.5$ & $34.6 \pm 0.6$ & ND & $5.1 \pm 0.3$ & $514.1 \pm 15.5$ \\
\hline
\end{tabular}

Continue... 


\begin{tabular}{|c|c|c|c|c|c|c|c|}
\hline \multicolumn{8}{|c|}{ Continued.. } \\
\hline \multirow{12}{*}{$\mathrm{P} 2$} & \multirow{2}{*}{ Root } & \multirow[b]{2}{*}{ FBC } & ND & $22.3 \pm 1.6$ & ND & $13.5 \pm 0.2$ & $121.6 \pm 6.6$ \\
\hline & & & & 2.9 & & 10.6 & 4.6 \\
\hline & \multirow{3}{*}{ Stem } & & ND & $12.9 \pm 3.4$ & ND & $22.5 \pm 0.1$ & $91.0 \pm 0.9$ \\
\hline & & \multirow{2}{*}{$\begin{array}{c}\text { FBC } \\
\text { FT }\end{array}$} & & 1.7 & & 17.7 & 3.4 \\
\hline & & & & 0.6 & & 1.7 & 0.7 \\
\hline & \multirow{3}{*}{ Leaf } & \multirow{3}{*}{$\begin{array}{c}\text { FBC } \\
\text { FT }\end{array}$} & ND & $8.4 \pm 0.3$ & ND & $22.2 \pm 0.2$ & $32.7 \pm 6.8$ \\
\hline & & & & 1.1 & & 17.5 & 1.2 \\
\hline & & & & 0.4 & & 1.6 & 0.3 \\
\hline & \multirow{3}{*}{$\mathrm{F} / \mathrm{S}$} & SM & ND & $12.1 \pm 0.6$ & ND & $21.9 \pm 1.2$ & $70.8 \pm 3.7$ \\
\hline & & \multirow{3}{*}{$\begin{array}{c}\text { FBC } \\
\text { FT }\end{array}$} & & 1.6 & & 17.2 & 2.7 \\
\hline & & & & 0.5 & & 1.6 & 0.6 \\
\hline & Sediment & & $2.7 \pm 0.2$ & $7.6 \pm 0.1$ & ND & $+^{(7)}$ & $26.7 \pm 0.7$ \\
\hline \multirow{12}{*}{ P3 } & \multirow{2}{*}{ Root } & \multirow{3}{*}{ FBC } & ND & $15.3 \pm 0.1$ & + & $21.9 \pm 0.1$ & $121.3 \pm 1.6$ \\
\hline & & & & 0.4 & & 4.8 & 0.5 \\
\hline & \multirow{3}{*}{ Stem } & & ND & $10.1 \pm 0.4$ & ND & $25.4 \pm 0.4$ & $27.5 \pm 1.4$ \\
\hline & & \multirow{3}{*}{$\begin{array}{c}\text { FBC } \\
\text { FT }\end{array}$} & & 0.3 & & 5.6 & 0.1 \\
\hline & & & & 0.7 & & 1.2 & 0.2 \\
\hline & \multirow{3}{*}{ Leaf } & & ND & $11.8 \pm 0.2$ & ND & $26.9 \pm 0.2$ & $46.5 \pm 2.9$ \\
\hline & & \multirow{3}{*}{$\begin{array}{c}\text { FBC } \\
\text { FT }\end{array}$} & & 0.3 & & 5.9 & 0.2 \\
\hline & & & & 0.8 & & 1.2 & 0.5 \\
\hline & \multirow{3}{*}{$\mathrm{F} / \mathrm{S}$} & & ND & $12.5 \pm 0.2$ & ND & $27.2 \pm 0.1$ & $61.3 \pm 2.1$ \\
\hline & & \multirow{3}{*}{$\begin{array}{c}\text { FBC } \\
\text { FT }\end{array}$} & & 0.3 & & 6.0 & 0.2 \\
\hline & & & & 0.8 & & 1.2 & 0.5 \\
\hline & Sediment & & $11.5 \pm 0.5$ & $40.0 \pm 0.2$ & $3.3 \pm 0.1$ & $4.6 \pm 0.1$ & $256.1 \pm 7.1$ \\
\hline \multirow{18}{*}{$\mathrm{P} 4$} & \multirow{2}{*}{ Root } & \multirow{3}{*}{ FBC } & ND & $6.7 \pm 0.7$ & ND & $27.9 \pm 0.2$ & $41.3 \pm 0.9$ \\
\hline & & & & 0.4 & & 9.4 & 0.2 \\
\hline & \multirow{3}{*}{ Stem } & & ND & + & ND & $32.2 \pm 0.6$ & $21.3 \pm 1.5$ \\
\hline & & \multirow{3}{*}{$\begin{array}{c}\text { FBC } \\
\text { FT }\end{array}$} & & & & 10.8 & 0.1 \\
\hline & & & & & & 1.2 & 0.3 \\
\hline & & & ND & + & ND & $31.4 \pm 0.6$ & $27.7 \pm 11.8$ \\
\hline & Leaf & FBC & & & & 10.5 & 0.1 \\
\hline & & FT & & & & 1.2 & 0.3 \\
\hline & & & ND & + & ND & $32.5 \pm 0.5$ & $61.7 \pm 1.1$ \\
\hline & $\mathrm{F} / \mathrm{S}$ & FBC & & & & 10.9 & 0.3 \\
\hline & & FT & & & & 1.3 & 1.5 \\
\hline & Sediment & & $6.0 \pm 0.2$ & $18.6 \pm 0.7$ & ND & $3.0 \pm 0.1$ & $216.2 \pm 2.4$ \\
\hline & $\mathrm{LOD}^{(7)}$ & & 4.5 & 0.8 & 1.1 & 2.3 & 3.5 \\
\hline & $\operatorname{LOQ}^{(8)}$ & & 15.0 & 2.8 & 16.3 & 7.7 & 11.5 \\
\hline & $\operatorname{LOD}^{(9)}$ & & 0.3 & 0.1 & 0.1 & 0.4 & 0.2 \\
\hline & $\operatorname{LOQ}^{(10)}$ & & 1.0 & 0.4 & 0.4 & 1.3 & 0.5 \\
\hline & $\mathrm{TEL}^{(11)}$ & & 37.3 & 35.7 & 35.0 & 18 & 123 \\
\hline & $\mathrm{PEL}^{(12)}$ & & 90.0 & 197 & 91.3 & 35.9 & 315 \\
\hline
\end{tabular}

$\mathrm{SD}^{(1)}=$ Standard Deviation; $\mathrm{ND}^{(2)}=$ Not Detected; $\mathrm{FBC}^{(3)}=$ Bioconcentration Factor; $\mathrm{FT}^{(4)}=$ Translocation Factor; $\mathrm{F} / \mathrm{S}^{(5)}=$ Fruit/Seed; (6) LOD <LOQ; (7) Detection limit for plant parts; (8) Quantification limit for plant parts; (9) Detection limit in the sediment; (10) Quantification limit in the sediment; (11) TEL (Threshold Effect Level): it limits the level of adverse effect on the biological community; (12) PEL (Probable Effect Level): probable level of adverse effect on the biological community. 
In general, the distribution of elements in sediments follows this order: $\mathrm{Zn}>\mathrm{Cu}>\mathrm{Cr}>\mathrm{Ni}>\mathrm{Pb}$. However, lead was only found in the sediment P3 $\left(3.3 \pm 0.1 \mathrm{mg} \mathrm{kg}^{-1}\right)$ and $\mathrm{Ni}$ was not detected in $\mathrm{P} 2$.

TEL and PEL, which are both related to fresh water parameters, are described in CCME (2002) Canadian Environmental Quality Guidelines and are the same as set forth in Resolution CONAMA 344/2004 for quality of sediment and fresh water (Conama, 2004). In the samples of sediments, $\mathrm{Cu}$ value was found near the TEL in P1 and above the TEL in P3; however, for $\mathrm{Zn}$, the value found in P1 was above the PEL and P3 and P4 were above the TEL (Table 2). Toxic metal levels found in these points may be related to the fact that these are drainage channels located very close to streets and paved avenues, with intense flow of motor vehicles. Wear of brakes and tires, road surface wear and re-suspension of road dust are the main sources of traffic pollution from vehicles. Tire wear dust is especially associated with the generation of significant amounts of metals such as $\mathrm{Zn}, \mathrm{Cd}, \mathrm{Co}, \mathrm{Cr}, \mathrm{Cu}, \mathrm{Hg}, \mathrm{Mo}, \mathrm{Ni}$, and $\mathrm{Pb}$ (Adamiec et al., 2016). And the hydrodynamic conditions can transport the concentrated metals in areas impermeable to the drainage channels (Poleto et al., 2009). Therefore, the $\mathrm{Zn}$ levels shown in P1 sediment are above PEL, and represent a risk for aquatic biota. These results are in agreement with those obtained by physicochemical data in Table 1.

In general, the analytes $\mathrm{Cu}, \mathrm{Ni}$ and $\mathrm{Zn}$ were found in all of the plant samples (root and aerial parts) from all of the collection points.

P1 belongs to a major storm water drainage channel running through the city and traveling through several neighborhoods. Therefore, the channel carries large effluent loads. This point presented all the analytes in higher concentrations in the sediment when compared to other points. In these samples, $\mathrm{Zn}$ had the highest concentration $\left(514.1 \pm 15.5 \mathrm{mg} \mathrm{kg}^{-1}\right)$.

In the plant samples (root and aerial parts), $\mathrm{Zn}$ showed a range from $88.5 \pm 1.0 \mathrm{mg} \mathrm{kg}^{-1}$ to $168.8 \pm 0.4 \mathrm{mg} \mathrm{kg}^{-1}$ and was followed by $\mathrm{Ni}$ (ranging from $12.6 \pm 1.0 \mathrm{mg} \mathrm{kg}^{-1}$ to $47.6 \pm 6.8 \mathrm{mg} \mathrm{kg}^{-1}$ ) and $\mathrm{Cu}$ (ranging from $6.8 \pm 0.3 \mathrm{mg} \mathrm{kg}^{-1}$ to $12.0 \pm 2.6 \mathrm{mg} \mathrm{kg}^{-1}$ ) respectively. For Ni, FBC $>1$ appeared in all of the plant organs (2.5 to 9.3) and in the stem and leaf FT $>1$ rates were found, where as $\mathrm{Cu}$ showed FT > 1 only in the stem.

The higher levels of metal concentrations (nutrients) show that this point had a greater amount of the macrophyte studied, which confirms the status of an impacted location.

P2 is characterized as a natural swamp in a rural area. As noted in Table 2, it is the place that showed lower concentrations of metals in sediments at the sampling points. In the plant samples (root and aerial parts), Zn ranged from $32.7 \pm 6.8 \mathrm{mg} \mathrm{kg}^{-1}$ to $121.6 \pm 6.6 \mathrm{mg} \mathrm{kg}^{-1}$, and showed only FBC $>1$ in all parts of the plant, ranging from 1.2 to 4.6. Although Ni was detected in the sediment, this element was found in all parts of the plant with values that ranged from $13.5 \pm 0.2 \mathrm{mg} \mathrm{kg}^{-1}$ to $22.5 \pm 0.1 \mathrm{mg} \mathrm{kg}^{-1}$, and $\mathrm{FBC}>1$ was also found in all plant organs (10.6 to 17.7) and FT > 1 in all its aerial parts (1.6 to 1.7). Cu had values ranging from $8.4 \pm 0.3 \mathrm{mg} \mathrm{kg}{ }^{-1}$ to $22.3 \pm 1.6 \mathrm{mg} \mathrm{kg}^{-1}$, showing only $\mathrm{FBC}>1$ in all parts of the plant that ranged from 1.1 to 2.9. Thus, $\mathrm{Zn}$ and $\mathrm{Cu}$ showed only $\mathrm{FBC}>1$, having most of these metals retained in the root. Moreover, the behavior between TF and FBC $>1$ in all parts of the plant in relation to Ni shows great bioavailability of this element in the sediment and the phytoextraction capacity of the plant (Ali et al., 2013).

P3 samples were collected in a converging stream inside a rainwater drainage channel. The results presented at this point differ from others because it is the only point that introduces $\mathrm{Pb}$ concentrations in sediment.

Both the root and the aerial parts presented values that range. For instance, $\mathrm{Zn}$ $\left(27.5 \pm 1.4 \mathrm{mg} \mathrm{kg}^{-1}\right.$ to $\left.121.3 \pm 1.6 \mathrm{mg} \mathrm{kg}^{-1}\right)$, Ni $\left(21.9 \pm 0.1 \mathrm{mg} \mathrm{kg}^{-1}\right.$ to $\left.27.2 \pm 0.1 \mathrm{mg} \mathrm{kg}^{-1}\right)$ and $\mathrm{Cu}$ $\left(10.1 \pm 0.4 \mathrm{mg} \mathrm{kg}^{-1}\right.$ to $\left.15.3 \pm 0.1 \mathrm{mg} \mathrm{kg}^{-1}\right)$. Ni was the only one which showed the presence of FBC $>1$ in all plant organs (4.8 to 6.0) and FT $>1$ in all its aerial parts (1.2), as shown in 
Table 2. Hence, FBC and TF $>1$ are in all parts of the plant relating to $\mathrm{Ni}$, showing great bioavailability of this element in the sediment and the phytoextraction capacity of the plant.

$\mathrm{P} 4$ is a ditch located on the shores of a paved street that is designed to receive storm water runoff. In all of the plant samples (root and aerial parts), $\mathrm{Zn}\left(21.3 \pm 1.5 \mathrm{mg} \mathrm{kg}^{-1}\right.$ to $\left.61.7 \pm 1.1 \mathrm{mg} \mathrm{kg}^{-1}\right)$ and $\mathrm{Ni}\left(27.9 \pm 0.2 \mathrm{mg} \mathrm{kg}^{-1}\right.$ to $\left.32.5 \pm 0.5 \mathrm{mg} \mathrm{kg}^{-1}\right)$ were found. Ni showed a presence of FBC $>1$ in all plant organs, ranging from 9.4 to 10.9 and showed FT $>1$ in all of its aerial parts, ranging from 1.2 to 1.3 , and $\mathrm{Zn}$ presented a TF $>1$ only in F/S (1.5). Cu was not detected in these plant parts and showed very low presence at the root value $\left(6.7 \pm 0.7 \mathrm{mg} \mathrm{kg}^{-1}\right)$ when compared to other elements.

In general, the distribution of analyte in plant parts (root, stem, leave and fruit/seed) followed this order: $\mathrm{Zn}>\mathrm{Ni}>\mathrm{Cu}$, variations that occur only in the root $\mathrm{P} 2(\mathrm{Zn}>\mathrm{Cu}>\mathrm{Ni})$ and $\mathrm{P} 4$ in the stems and leaves $(\mathrm{Ni}>\mathrm{Zn})$. Zn was found in higher concentrations in all sample roots and in almost all the aerial parts of the plants, located in all collection points. However, this element has been overcome by Ni concentrations that were found in samples from P4 stems and leaves.

Vardanyan and Ingole (2006) used in their studies, among other plants - Sagittaria sagittiflia $\mathrm{L}$., and found values of $\mathrm{Cu}$ and $\mathrm{Ni}$ concentrations in the following order: root $>$ leaf $>$ stem. However, for Zn concentrations, the order followed as such: leaf $>$ root $>$ stem. Although both plants belong to the same family, the results of $S$. montevidensis have been quite divergent. The $\mathrm{Cu}$ concentrations were distributed in this order: root $>$ stem>leaf; $\mathrm{Ni}$, leaf $>$ stem $>$ root; and $\mathrm{Zn}$, root $>$ leaf $>$ stem. According to these authors, the interactions between these metals are often complex and dependent on metal concentrations and $\mathrm{pH}$ of growth medium.

Overall, a strong correlation can be observed between the sampled points and these plants. Apart from P4 relating to stems and leaves, all plants, in the roots, stems, leaves and fruits/seeds, showed the same profile of the studied metals, which is highlighted by Pearson correlation coefficients (Table 3). In this table, we also notice that the roots and fruits/seeds presented the best coefficients for all the points, which proves its use as a bioindicator species.

Table 3. Pearson ratio coefficient of correlation between metals levels $(\mathrm{Cr}, \mathrm{Cu}, \mathrm{Ni}$, $\mathrm{Pb}$ and $\mathrm{Zn})$ found in different plant parts $\left(\mathrm{mg} \mathrm{kg}^{-1}\right) \mathrm{x}$ metal levels $(\mathrm{Cr}, \mathrm{Cu}, \mathrm{Ni}, \mathrm{Pb}$ and $\mathrm{Zn})$ found in sediments $\left(\mathrm{mg} \mathrm{kg}^{-1}\right)$ in P1, P2, P3 and P4.

\begin{tabular}{lcccc}
\hline & P1 & P2 & P3 & P4 \\
\hline Root & 0.99 & 0.98 & 0.98 & 0.78 \\
Stem & 0.96 & 0.94 & 0.62 & 0.06 \\
Leaf & 0.88 & 0.74 & 0.82 & 0.18 \\
F/S & 0.99 & 0.93 & 0.89 & 0.85 \\
\hline $\mathbf{r}^{(\mathbf{2})}$ & & & & $\mathbf{0 . 7 5}$ \\
\hline
\end{tabular}

F/S ${ }^{(1)}$ Fruit/ Seed; $\mathbf{r}^{(2)}$ Total sediment correlation metals and organic matter content.

In this study, Point P2 had lower elements and the lowest number in the studied plant; and Points P1, P3 and P4 had higher values for the same elements and larger quantities in the same plant. Such behavior confirms S. montevidensis' characteristics for bioindication and phytoextraction for the metals studied, mainly for $\mathrm{Cu}, \mathrm{Ni}$ and $\mathrm{Zn}$.

The quality control of the results obtained in the recovery values ranged between 76.6 to $106.2 \%$ for most of the metals studied, in both the reference materials for sediment and in the matrices for aquatic plants. According to Jesus et al. (2004), recovery factors between 75 and $110 \%$ are considered satisfactory (Table 4). Only chrome was reported to be $66.7 \%$ recovery, 
possibly because it is a pseudo-total digestion and the reference value is relative to the total digestion of that reference material.

Table 4. Recovery in $\mathrm{mg} \mathrm{kg}^{-1} \pm \mathrm{SD}$ obtained from Trapa natans, (Aquatic plant) to $\mathrm{Cr}$, Lagarosiphon major (Aquatic plant) and Natural Matrix Certified Reference-soil and sediment to $\mathrm{Cu}$, $\mathrm{Pb}, \mathrm{Ni}$ and $\mathrm{Zn}$.

\begin{tabular}{cccccccccc}
\hline \multicolumn{4}{c}{ Lagarosiphon major } & \multicolumn{3}{c}{ Trapa natans } & \multicolumn{3}{c}{ NMCR\#4 } \\
\hline & $\mathrm{VC}^{(\mathbf{1})}$ & $\mathrm{V}^{(2)}$ & $\mathrm{Rec}^{(\mathbf{3})}$ & $\mathrm{VC}$ & $\mathrm{V}$ & $\mathrm{rec}$ & $\mathrm{VC}$ & $\mathrm{V}$ & $\mathrm{Rec}$ \\
\hline $\mathrm{Cr}$ & & & $36.3 \pm 1.7$ & $32.4 \pm 1.6$ & 89.3 & $48.1 \pm 6.6$ & $32.1 \pm 3.2$ & 66.7 \\
$\mathrm{Cu}$ & $51.2 \pm 1.9$ & $52.5 \pm 1.1$ & 102.5 & & & & $36.4 \pm 2.2$ & $34.2 \pm 1.8$ & 94.0 \\
$\mathrm{~Pb}$ & $94.0 \pm 4.0$ & $72.0 \pm 2.0$ & 76.6 & & & & $95.3 \pm 7.7$ & $98.6 \pm 3.2$ & 103.5 \\
$\mathrm{Ni}$ & 40.0 & $42.5 \pm 1.7$ & 106.2 & & & & $26.0 \pm 3$ & $22.4 \pm 1.3$ & 86.2 \\
\hline $\mathrm{Zn}$ & $313.0 \pm 8.0$ & $310.4 \pm 2.6$ & 99.1 & & & & $133.5 \pm 10.6$ & $118.8 \pm 0.2$ & 89.0 \\
\hline $\mathrm{VC}^{(\mathbf{1})}$ Certificate value; $\mathrm{V}^{(\mathbf{2})}$ Found value; Rec $^{(\mathbf{3})}$ \% recovery.
\end{tabular}

\section{CONCLUSION}

The studied species is adequate for bioindication since it presents resistance to impacted environments and reflects the profile and bioavailability of toxic metals. Among the studied analytes, there is Ni bioconcentration capacity with high Bioconcentration Factor (FBC) values and Translocation Factor (TF) which shows a phytoextraction species for that element. However, for other metals, low translocation values were presented.

Considering the results, it is concluded that $S$. montevidensis has the capacity for phytoextraction, mainly for $\mathrm{Ni}$, and may potentially act as a bioindicator for $\mathrm{Cu}, \mathrm{Ni}$ and $\mathrm{Zn}$.

\section{ACKNOWLEDGEMENTS}

We would like to thank Professor Raquel Lüdtke of the Institute of Biology Departamento de Botânica - UFPel - Campus Universitário Capão do Leão for the identification of plants and the Pro-rectory of Research, Innovation and Post-graduation (PROPESP) IF-Sul for the support.

\section{REFERENCES}

ABREU, C. A.; FURlani, A. C.; ABREU, M. F.; BATAGliA, O. C.; FURLANI, P. R. Micronutrient determination in different water extracts of coir fiber substrate incubated with mineral fertilizers. In: INTERNATIONAL SYMPOSIUM ON SOILLESS CULTURE AND HYDROPONICS, 14-19 nov. 2004, Alméria. Procedings... Korbeek: ISHS, 2005. p. 113-114.

ADAMIEC, E.; KRZEMINSKA, E. J.; WIESZALA, R. Heavy metals from non-exhaust vehicle emissions in urban and motorway road dusts. Environmental monitoring and assessment, v. 188, n. 369, p. 1-11, 2016. http://dx.doi.org/10.1007/s10661-016-5377-1

ANDRADE, M. A; MARANHO, L. T.; PREUSSLER, K. H.; CUBAS, S. Organização estrutural da raiz e folha de Sagittaria montevidensis Cham. and Schltdl., Alismataceae. Revista Brasileira de Biociências, v. 5, n. 1, p. 117-119, 2007. 
ALI, H.; KHAN, E.; SAJAD, M. A. Phytoremediation of heavy metals - Concepts and $\begin{array}{llllllll}\text { applications. Chemosphere, } & \text { v. } 91, \quad \text { n. } 7, \quad \text { p. } 869-881,\end{array}$ http://dx.doi.org/10.1016/j. chemosphere.2013.01.075

AMERICAN PUBLIC HEALTH ASSOCIATION - APHA. Standard methods for the examination of water and wastewater. 21.ed. New York, 2005. 937 p.

BALABANOVA, B.; STAFILOV, T.; BAČEVA, K. Bioavailability and bioaccumulation characterization of essential and heavy metals contents in R. acetosa, S. oleracea and U. dioica from copper polluted and referent areas. Journal of Environmental Health

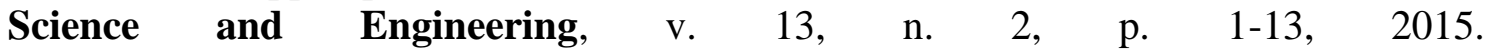
http://dx.doi.org/10.1186/s40201-015-0159-1

BEVILAQUA, G. A. P.; NEDEL, J. L.; ZUANAZZI, J. A.; CORREA, C. T. Distribuição geográfica e composição química do chapéu-de-couro (Echinodorus spp.) no Rio grande do Sul. Ciência Rural, v. 32, n. 2, p. 213-218, 2001. http://dx.doi.org/10.1590/S0103-84782001000200004

BRASIL. Secretaria de Vigilância em Saúde. Vigilância e controle da qualidade da água para consumo humano. Brasília, 2006. 212 p.

BREGUNCE, B. T.; VEIGA, B. V.; MARANHO, L. T.; CUBAS, S. A. Avaliação de sistema de leito cultivado com a macrófita Sagittaria montevidensis Cham. \& Schltdl. para tratamento de águas urbanas poluídas. Revista Brasileira de Biociências, v. 9, n. 1, p. 86-95, 2011. http://www.ufrgs.br/seerbio/ojs/index.php/rbb/article/view/1430

CALDAS, J. S.; SANCHES FILHO, P. J. Determinação de Cu, Pb e Zn no sedimento da região do Pontal da Barra, Laranjal (Laguna dos Patos, Pelotas - Brasil). Brazilian Journal Aquatic Science Technology, v. 17, n. 1, p. 13-18, 2013. http://dx.doi.org/10. 14210/bjast.v17n1.p13-18

CANADIAN COUNCIL OF MINISTERS OF THE ENVIRONMENT - CCME. Canadian Sediment Quality Guidelines for the protection aquatic life. Winnipeg, 2002.

CASSOL, B.; AGOSTINETO, D.; MARIATH, J. E. A. Análise Morfológica de Sagittaria montevidensis Desenvolvida em Diferentes Condições de Inundação. Planta Daninha, v. 26, n. 3, p. 487-496, 2008. http://dx.doi.org/10.1590/S0100-83582008000300003

COMPANHIA DE TECNOLOGIA DE SANEAMENTO AMBIENTAL - CETESB. Significado ambiental e sanitário das variáveis de qualidade das águas e dos sedimentos e metodologias analíticas e de amostragem. São Paulo, 2009.

CONSELHO NACIONAL DO MEIO AMBIENTE (Brasil). Resolução no 344 de 25 de março de 2004. Estabelece as diretrizes gerais e os procedimentos mínimos para a avaliação do material a ser dragado em águas jurisdicionais brasileiras, e dá outras providências. Diário Oficial [da] União, Brasília, DF, n. 87, de 7 de maio de 2004, Seção 1, p. 57-57.

CONSELHO NACIONAL DO MEIO AMBIENTE (Brasil). Resolução nº 357 de 17 de março de 2005. Dispõe sobre a classificação de corpos de água e diretrizes ambientais para o seu enquadramento, bem como estabelece as condições e padrões de lançamento de efluentes, e dá outras providências. Diário Oficial [da] União, Brasília, DF, n. 53, 18 de março de 2005, Seção 1, p. 58-63. 
DEMARCO, C. F.; NAZARI, M. T.; CAMARGO, F. A. de O.; QUADRO, M. S.; PIENIZ, S.; ANDREAZZA, R. Seleção de Macrófitas Aquáticas com Potencial de Fitorremediação no Arroio Santa Bárbara, Município de Pelotas/RS. In: ENCONTRO NACIONAL DE ESTUDANTES DE ENGENHARIA AMBIENTAL, 14., Oct. 2016, Brasília. Proceedings... São Paulo: Blucher, 2016. p. 72-79.

DHIR, B.; SHARMILA, P.; SARADHI, P. P. Potential of aquatic macrophytes for removing contaminants from the environment. Critical Reviews in Environmental Science and $\begin{array}{lllllllll}\text { Technology, } & \text { v. } 39, \quad \text { n. } & 9, & \text { p. } & 754 & - & 781,\end{array}$ http://dx.doi.org/10.1080/10643380801977776

HORTELLANI, M. A.; SARKIS, J. E. S.; BONETTI, J; BONETTI, C. Evaluation of mercury contamination in sediments from Santos - São Vicente Estuarine System, São Paulo State, Brazil. Journal of the Brazilian Chemical Society, v. 16, n. 6a, p. 1140-1149, 2005. http://dx.doi.org/10.1590/S0103-50532005000700009

INTERNATIONAL UNION OF PURE AND APPLIED CHEMISTRY - IUPAC. Compendium of chemical terminology. $2^{\text {nd }}$ Edition. [S.1.]: Wiley, 1997.

JESUS, H. C.; COSTA, E. A.; MENDONÇA, A. S. F.; ZANDONADE, E. Distribuição de metais tóxicos em sedimentos do sistema estuarino da Ilha de Vitória-ES. Química Nova, v. 27, n. 3, p. 378-386, 2004. http://dx.doi.org/10.1590/S0100-40422004000300004

MIRLEAN, N.; ANDRUS, V. E.; BAISCH, P. Mercury pollution sources in sediments of Patos Lagoon Estuary, Southern Brazil. Marine Pollution Bulletin, v. 46, n. 3, p. 331-334, 2003. http://dx.doi.org/10.1016/S0025-326X(02)00404-6

MOLISANI, M. M.; ROCHA, R.; MACHADO, W. Mercury contents in aquatic macrophytes from two reservoirs in the Paraíba do Sul: Guandú river system, SE Brazil. Brazilian Journal of Biology, v. 66, n. 1A, p. 101-107, 2006. http://dx.doi.org/10.1590/S1519-69842006000100013

POlETO, C.; BORTOLUZZI, E. C.; CHARLESWORTH, S. M.; MERTEN, G. H. Urban sediment particle size and pollutants in Southern Brazil. Journal of soils and sediments, v. 9 n. 4, p. 317-327, 2009. http://dx.doi.org/10.1007/s11368-009-0102-0

SANCHES FILHO, P. J.; NUNES, L. V.; ROSA, N. N. da; BETEMPS, G. R.; PEREIRA, R. S. Comparison among native floating aquatic macrophytes for bioconcentration of heavy metals. Ecotoxicology Environmental Contaminants, v. 10, n. 1, p. 1-6, 2015. http://dx.doi.org/10.5132/eec.2015.01.01

SARKINNOMA, A.; YARKASUWA, C. I.; MODU, K. A. Analysis of Physicochemical Parameters of Sewage Water used for Irrigation in Bauchi Metropolis - Nigeria. Journal of Environment and Earth Science, v. 3, n. 10, 2013.

SHEORAN, V.; SHEORAN, A.; POONIA, P. Role of hyperaccumulators in phytoextraction of metals from contaminated mining sites: a Critial Reviews in Environmental Science $\begin{array}{llllll}\text { and Technology, } & \text { v. } & \text { 41, } & \text { p. }\end{array}$ http://dx.doi.org/10.1080/1064338090 2718418

TANGAHU, B. V.; ABDULlAH, S. R. S.; BASRI, H.; IDRIS, M.; ANUAR, N.; MUKHLISIN, M. A review on heavy metals (As, $\mathrm{Pb}$, and $\mathrm{Hg}$ ) uptake by plants through phytoremediation. International Journal of Chemical Engineering, v. 1, p. 1-31, 2011. http://dx.doi.org/10.1155/2011/939161 
THOMAZ, S. M.; BINI, L. M. Ecologia e manejo de macrófitas aquáticas. 1. ed. Maringá: EDUEM, 2003. 341 p.

VARDANYAN, L. G.; INGOLE, B. S. Studies on heavy metal accumulation in aquatic macrophytes from Sevan (Armênia) and Carambolin (Índia) lake systems. Environment International, v. 32, n. 2, p. 208-218, 2006. http://dx.doi.org/10.1016/j. envint.2005.08.013 